\title{
Risk Factors Associated With Under-Five Diarrhea and Their Effect on Under-Five Mortality in Rwanda: Secondary Data Analysis of 2014-2015 Rwanda Demographic and Health Survey (Rdhs).
}

Jean Bosco NDIKUBWIMANA ( $\square$ ndikujeanbosco@gmail.com )

University of Rwanda https://orcid.org/0000-0001-5154-8218

Frederic NGENDAHIMANA

University of Rwanda, ACE-DS

Angelique DUKUNDE

University of Rwanda, ACE-DS, UoK

Evariste GATABAZI

University of Kigali (UoK)

Faustin HAKIZIMANA

University of Kigali (UoK)

Research Article

Keywords: Diarrhea, Diarrhea mortality,under-five, RDHS, Rwanda

Posted Date: August 19th, 2021

DOI: https://doi.org/10.21203/rs.3.rs-827820/v1

License: (c) (1) This work is licensed under a Creative Commons Attribution 4.0 International License.

Read Full License 


\section{Abstract}

Aims: Diarrhea claimed to be among the leading cause of childhood mortality in developing countries include Rwanda despite its simple protection measures. The current study intended to elucidate the image of childhood diarrhea and to sort out which strong causes are linked to this phenomenon in Rwanda. Therefore, contribute, on the basis of a quantitative analysis outcome, to good policymaking oriented to the enhancement of the welfare of children in Rwanda and the second target of SDGs of ensuring child survival.

Methods: Data were obtained from RDHS2015 in the child's file. Following the inclusion criteria of having at least one under-five child in a household and that child has full records on her/his diarrhea status during the last two weeks preceding the survey, a total of 7474 children met the criteria and were thus included in the analysis. The selection of variables was guided by Genser B. and colleagues' theory. Descriptive, and bivariate analyses were performed. Identified variables were statistically associated with childhood diarrhea in Rwanda and were subsequently considered into the multivariate analysis of the strongest causes of childhood diarrhea in Rwanda.

Results: The descriptive analysis revealed that among 7474 sampled under-five children, $12.11 \%$ have been infected by diarrhea during the two weeks preceding the survey. The bivariate analysis revealed that type of place of residence, mother's education level, anemia level of the child, type of toilet facility, sharing the toilet with other households, time to get water source, source of drinking water, poverty, child's age, and main floor material are statistically associated with the prevalence of childhood diarrhea in Rwanda and thus was selected to be predicting childhood diarrhea based on their significance level and confidence interval. The reduced model of binary logistic regression revealed that only being aged below three years, living in a poor family, and uses an improved toilet increases the chances of childhood diarrhea infection.

Conclusions: Childhood diarrhea can be effectively managed with reasonable outcomes by strengthening the sanitation system with more focus on rural areas families especially the poorest families; reinforcement of the Ministry of Health, and other related measures to mitigate the identified issues. Also, periodically research is highly needed on all levels of children not only on diarrhea in order to help national level planning in various sectors.

\section{Introduction}

The health of newborn and under five children remains worrying in developing countries. The highest rates of neonatal and child mortality are still in Sub-Saharan Africa, where on average 109 children out of 1000 live births die before the age of five whereas in the developed countries, only 7 children out of 1000 live births die before the age of 5 and where 34 newborns out of 1000 live births die before 28 days of life, whereas only 4 newborns out of 1000 live births dies before 28 days of life in developed countries as reported by Rwanda Biomedical Center (RBC, 2013). 
The recent report of United Nations Children Fund (UNICEF, 2015) revealed that over 1,400 young children dying each day, or about 526,000 children ayear. This translates 9 per cent of all deaths among children under age 5 worldwide. These deaths are concentrated in developing countries include Rwanda. This was confirmed also by (Lancet, 2017) in its systematic review of global diseases burden, it revealed that there have been a decline in diarrhea deaths related mortality of 34 percent from 2005 up to 2015 . Though it seems to make a significant improvement, the same study reported that in 2015 Half a million children under the age of five died from diarrhea-related illnesses. This is equal to 499,000 children under five and 1.3 million people of all ages and this push them to rank it the fourth leading killer of under five children globally.

In addition, the world health organization (WHO, 2017a) in its recent updates, it ranked diarrhea as the second leading cause of under five mortality as indicated by figure 1 . This is rooted from its responsiveness of 525000 children under five deaths each year.

Considering different geographical location, some countries of Africa had very high childhood diarrhea prevalence worldwide for instance Chad and Niger whose 594 and 485 deaths respectively per 100,000 children (Lancet, 2017). Though sub Saharan Africa posses the great share of childhood diarrhea related deaths, it have showed a significant decrease in diarrhea related deaths where deaths fell from 445 to 277 for every 100,000 children between 2005 and 2015(UNICEF, THE WORLD BANK GROUP, WHO, \& UN, 2015).

Moreover, it is surprisingly that while deaths from diarrheal illnesses are rare in high-income countries, there was a $15.4 \%$ increase in the number of reported cases in such regions over the past decade. In the UK, 30 children under the age of five died in 2015 and there were roughly 1,500 deaths overall from diarrheal illnesses, a reduction of $18.5 \%$ since 2005 .

In spite of this persisted higher childhood diarrhea prevalence across the regions, it can be easily managed with simple and affordable measures: access to safe drinking-water; use of improved sanitation; hand washing with soap; exclusive breastfeeding for the first six months of life; good personal and food hygiene; health education about how infections spread; and rotavirus vaccination(WHO, 2017b).

Rwanda decline in childhood diarrhea prevalence $(\mathrm{RBC}, 2013)$. Though the country put in place numerous strategies to eradicate the infectious diseases for instance diarrhea where it targeted the childhood diarrhea prevalence of $11 \%$ and $9 \%$ in 2015 and 2018 respectively down from 13\% in 2010 but the recent Rwanda Demographic and Health Survey (NISR, MINECOFINE, MOH, ICF International, \& USA, 2016) revealed that this prevalence is still 12 percent and highly concentrated among children aged between 12-23 months and 6-11 months (22 percent and 18 percent, respectively). This is accompanied by a failure to achieve a $50 \%$ increase in both Population using improved drinking-water sources and Population using improved Sanitation where (Africa Health Observatory \& WHO, 2016) reported the decline were on $42 \%$ for both targets. This goes in line also with the higher infant mortality 32 deaths per 1000 live births (NISR et al., 2016) against a target of 28 deaths per 1000 live births( $\mathrm{MOH}, 2015)$ and 
under five mortality prevalence (in rural areas). Thus, after examining the relationship between poor sanitation indicators and childhood diarrhea, this study will explore also the effect of childhood diarrhea on under-five mortality in Rwanda. Therefore, contribute to the existing body of knowledge and being at the same time a sight for decision makers regarding the realization of health sector strategic plan in Place.

Childhood diarrhea is a major public health concern in Rwanda. It is the third leading cause of under-five morbidity and mortality. Deaths from diarrheal disease account for one fifth of all childhood deaths as indicated by figure 3 :

The government put in place many preventive measures to compact the disease for instance: increase the coverage of improved water sanitation, using unique improved toilet facility and hand washing with sop before and after using toilet or feeding babies as well as making its treatment available and affordable using community health workers the disease continues to ravage many children below the age of five. In addition, some study and reports revealed that hygienic practices is still challenging in Rwanda (RBC, 2015). This study concluded that in western district of Rwanda, among the surveyed infected households; $25 \%$ of them did not practice hand washing and even $30 \%$ did not have soap, $71 \%$ had unclean toilet and Less than half of the respondents had heard information about the appropriate prevention measures for cholera. Moreover, at country level, the sanitation indicators are behind the targets. There was only an increase of only $42 \%$ on both percentage of population using improved drinking-water sources and population using improved sanitation against a target of $50 \%$ (Africa Health Observatory \& WHO, 2016). During the same year, there were slight declines in childhood diarrhea prevalence of $1 \%$. However, considering that the country targeted that prevalence to decline to $11 \%$ in 2015 and 9\% in 2018 (RBC, 2013) it seems that it is a dream to met the targets. This is proven by the under- five diarrhea prevalence of $12 \%$ (which is above the target) that even goes far above the target considering children aged between 12-23 months and 6-11 months (22 percent and 18 percent, respectively)(NISR et al., 2016). This report notice a significant difference of childhood diarrhea prevalence in rural areas than urban areas which the same for under-five mortality. The child mortality rate is far above the target in rural areas (78deaths per 1000 live births against a target of 50 deaths per 1000 live births) but it is aggregated by the urban figures to met an overall country target of 50 deaths per 1000 live births. On the other hand, infant mortality rate wee behind the target in the same year 32 deaths per 1000 live births against a target of 28 deaths per 1000 live births (MOH, 2015).

Thus, this study will investigate the demographic, socio-economic and environmental sanitation practices indicators associated with this persistence high prevalence of diarrhea among under-five children and the existing effect of childhood diarrhea on childhood mortality in Rwanda. The main objective is to determine the demographic, socio-economic and environmental risk factors associated with under-five diarrhea in Rwanda. Specifically, the paper find out the effect of childhood diarrhea on childhood mortality in Rwanda; provide recommendations on critical areas of intervention in favor of under-five children survival in Rwanda. 


\section{Literature Review}

we present an array of researchers who conducted scientific studies on childhood diarrhea and childhood mortality worldwide by focusing on the linkage between sanitation practices indicators and under five diarrheas as well as its effect on child mortality. Some key terms are: Under five children: Living children not yet celebrating their fifth birth day; Under-five mortality: the probability of a child dying before reaching the age of five year; Infant mortality: the probability of a child dying before his or her first birthday (UN, 2013); Diarrhea: According to the World Health Organization (WHO, 2013), diarrhea is "the passage of three or more loose or liquid stools per day, or more frequently than is normal for the individual." If left untreated, diarrhea can lead to severe dehydration, which can result in hospitalization or even death.

\subsection{Environmental factors of childhood diarrhea prevalence}

Poor environmental infrastructure is associated with poor sanitation practices(Genser, Strina, Prado, Barreto, \& Cairncross, 2008) , (O Connell, Quinn, \& Scheuerman, 2017) and (Mohammed \& Zungu, 2016). Mohammed and his colleague tried to investigate the Socioeconomic factors associated with diarrheal diseases among under-five children of the nomadic population in northeast-Hadaleala District of Ethiopia using cross-section data collected for 704 under-five children and analyzed using multivariable logistic regression method to identify socioeconomic variables associated with childhood diarrhea and revealed four variables that are protective factors for childhood diarrhea: type of toilet facility(Un improved/improved), availability of specific hand-washing places(available/not available), availability of hand-washing facilities(available/not available) and mothers' knowledge on diarrhea causation(poor/good). This was confirmed by (Uwizeye, okoni, \& Kabiru, 2014) in their study correlates of diarrhea in MATYAZO cell of HUYE town in Rwanda and found that being far from roads, poor sanitation and rainy seasons increases the likelihood of being infected by diarrhea among peoples in all ages. Un like them, not only (O Connell et al., 2017) who analyzed the RDHS2010 and concluded that the childhood diarrhea prevalence is independent on type of Water Source and type of sanitation facility in Rwanda but also (Sinharoy et al., 2016) in their study where they tried to explore the associations of environmental and demographic factors with diarrhea and nutritional status among children in Rusizi district of Rwanda using cross-sectional data collected for 8847 households and analyzed using Log-binomial regression models and concluded also that the treatment of drinking water (any method) is inversely associated with caregiver-reported diarrhea in the previous 7 days ( $P R=0.79,95 \% \mathrm{Cl}: 0.68-0.91)$ and this is differs of what (KIMANI, 2013) found in his study. His study concluded that water treatment did not have any association with childhood diarrhea.

Moreover, (Danquah, Mensah, Agyemang, \& Awuah, 2015)in their study where they investigated risk factors associated with diarrhea morbidity among children younger than five years in the atwimanwabiagya district of Ghana using cross section data collected in dry season on 378 households supported what Mohammed and his colleague which is the same for sinharoy and colleagues found in Rwanda by concluding that type of toilet facility (public / private) is independent of childhood diarrhea 
prevalence in that region. The former added also that the disease is independent on the distance to water source.

\subsection{Socio-Demographic factors of childhood diarrhea prevalence}

Socio-demographic factors are taken as the proximate determinants of childhood diarrhea prevalence as pointed by many researchers for instance (Ganguly, Sharma, \& Bunker, 2015) their meta analysis, the investigated the Prevalence and risk factors of diarrhea morbidity among under-five children in India using a systematic review of comprehensive electronic search of relevant medical subject heading and revealed a significant association with anemia level of the child, and low socioeconomic status. Unlike other researchers; Age of the child ( $<24$ months), mothers' low literacy status and untreated drinking water did not show a significant association. Sex of the child, religion, higher education of mothers, and seasonality were found to be inconsistently associated in single studies. This is not the same for $(0$ Connell et al., 2017) in their study where they tried to investigate the Risk factors of diarrheal disease among children in the East African countries of Burundi, Rwanda and Tanzania using Demographic and Health Surveys (DHS) Program Data on child health in those countries from 2010 using simple and multiple logistic regressions to identify predictors of diarrhea and concluded that young mothers, and the mother's education level (secondary school or less) have a very significant association with childhood diarrhea prevalence considering both Burundian and Rwandese children. It further revealed that unlike in the Burundi, seasonality in favor of rainy season increases the likelihood of being infected in the other countries.

This goes in line of what Mohammed and his colleague found where they concluded that Age( in favor of 6-11 months; $12-23$ months; 24-35 months) of child, number of children below five-years (in favor of 2 and 3 children), and mother education level (Illiterate mothers) were found to be associated with childhood diarrhea prevalence. Unlike them (Danquah et al., 2015) didn't found any significant childhood association considering number of under five children in a household but confirmed its association with mother' age and mother' education level.

\subsection{Socio-economic factors of childhood diarrhea prevalence}

Poor socioeconomic increases diarrhea risk, mostly mediated by lack of sanitation, poor infrastructure and living conditions (Genser et al., 2008). This is because it is difficult for poor families to afford improved sanitation practices and higher education as the perquisite in terms of awareness or accessibility. In their study of the impact of sanitation practices on childhood diarrhea, (Genser et al., 2008) concluded that a sanitation intervention in a given infected population can have a substantial impact on the epidemiology of child diarrhea. Improving sanitation decreases the attributable risk of diarrhea determinants directly by reducing exposure to these factors, or indirectly by changing the strength of associations with them. This is confirmed by (Ngabo et al., 2016) in their study of the economic burden of childhood diarrhea in Rwanda. They found that Households often bear the largest share of the economic burden attributable to diarrhea hospitalization and the burden can be substantial, especially for households in the lowest income quintile. The same findings for (Mohammed \& Zungu, 
2016) who found also that household wealth (poor households) has a positive association with childhood diarrhea. This differs from what (O Connell et al., 2017) found by considering different population of Rwanda, Burundi and Tanzania. The associated were confirmed only for Rwandese children.

\subsection{Childhood diarrhea and childhood mortality}

Untreated diarrhea can kills peoples especially younger children. When a person gets diarrhea, the body begins to lose a lot of water and salts or electrolytes (sodium, chloride, potassium and bicarbonate). They are normally lost through liquid stools, vomit, sweat, urine and breathing, they are all necessary for life but if the water and salts are not replaced fast, the body starts to "dry up" or get dehydrated. Severe dehydration can cause death especially for children less than five years of age (Nasser, 2014). It is the second leading cause of morbidity and mortality worldwide (WHO, 2017a) and the third leading cause of under five morbidity and mortality in Rwanda $(\mathrm{MOH}, 2014)$. The developing countries especially the ones from sub Saharan Africa have the biggest share of the world's total deaths due to diarrhea $(98.7 \%$ and 49.6\% respectively)(UNICEF et al., 2015).

Some authors concluded that it even kills than HIV and malaria when combined (Centers for Disease Control and Prevention, 2014). This center further reported that diarrhea causes stunting and wasting as well as cognitive development. On the other hand Some researcher did not show any significant association between diarrhea and mortality. For example (Simms, Milimo, \& Bloom, 1993) analyzed the reasons for the rise in unde-five mortality but he found that for the same period the under-five diarrhea prevalence were decline.

This research is based on (Mosley \& Chen, 1984) theoretical framework to reach its objectives. Though this model was conceived to point out determinants of under-five mortality, it has been a standard instrument in analyzing and understanding under-five mortality. Mosley and Chen's model consolidates both socioeconomic and proximate factors as main determinants of under-five children's mortality. Biological factors are considered as direct factors whereas socioeconomic factors are considered as indirect factors in their conceptual framework.

They enlarged Chen's framework by grouping determinants of under-five mortality into 5 categories relating to (1) environmental contamination, (2) maternal factors (3) nutrient availability, (4) injuries and (5) disease control. They grouped these factors into direct and indirect risk factors.

The direct factors comprise a) maternal factors (age at birth, parity, and birth intervals), b) nutrient deficiency factors (nutrient availability to the infant and to the mother during pregnancy and lactation), c) injuries (recent injuries or injury-related disabilities), d) environmental contamination factors (intensity of household crowding, water and food contamination, housing conditions, energy availability...), e) personal illness control (use of preventive services as immunizations, malaria prophylactics or antenatal care, and use of curative measures for specific conditions). 
The indirect factors are made of a) Individual level factors (skills, health and time, usually measured by mother's educational level, tradition/norms/attitudes, beliefs about disease causation...), b) Household level factors (food availability, clothing, transportation, daily hygienic and preventive care, access to information...), c) Community level factors (climate, temperature, altitude, season, rainfall, health system variables...).

In this perspective, Mosley and Chen's following conceptual model enlightened my path to the formulation of the hypothesis and problem statement as shown in Figure 5:

Mosley and Chen here above show us how under-five mortality phenomenon is caused by an aggregate of risk factors. Proximate and socioeconomic determinants interact and lead to under-five mortality. Environmental, nutrient deficiency factors associated with maternal, personal illness control and injury related factors affect positively or negatively a child by giving him a healthy and sickness status. The sickness status could be a cause of a child's growth faltering or death. Direct determinants are directly linked to child survival whereas socioeconomic or indirect factors influence under-five mortality when they are combined with the first one.

However this modifies the model to fit the available variables in the RDHS2015 database file. This study excludes nutrient deficiency and injury factors mentioned in Mosley and Chen's model because the RDHS 2015 did not collect such information at the time of the survey. It also eliminates personal illness control in form of diarrhea treatment/ oral rehydration therapy because the focus of the study is to determine the risk factors associated with childhood diarrhea and not the diagnosis platform. Thus, in this study variables were regrouped into: socio-economic, socio-demographic and environmental variables.

a) Social economic status: These include the mother's education levels, marital status and the household's income levels.

b) Environmental factors: These factors include sanitation and living conditions for example sewerage systems, source of water supply, nature and type of toilets as well as both household and personal hygiene behavior.

c) Socio-demographic factors: These factor include age and gender of the child's care giver respectively. Like in the mosley and chen model, both environmental factors and socio-demographic factors are the proximate determinants of childhood diarrhea whereas socio-economic factors are taken as effect modifiers.

The main concepts in this model are subdivided into: Environmental factors: These include Household Living condition variables (those variables will help us to know the level of hygienic practices in households) and Infrastructure and sanitation variables (Those variables will help us to assess the household's neighboring infrastructure that could affect the health of the child). Socio-Demographic Factors: These variables indicates disparities among different level of demographic factors and Include 
age of the child, mother's education level, number of siblings below five years in a household and seasons. Socio-economic variables: these variables indicate the affordability of hygienic practices and include the place of residence and wealth index. These factors are operating through the direct factors as effect modifiers.

\section{Materials And Methods}

This is a cross-sectional study design of the RDHS2015 data. Those data were collected at country level with the help of well trained enumerators using a questionnaire in kinyarwanda. 30058 children were sampled using a multi stage sampling technique. The first stage involved the selection of establishment (Village) in each strata (Sector) whereas the second stage involved the systematic selection of establishments units (Household). The design is chosen since it is meant to determine risk factors associated with diarrhea incidences among the under five children in Rwanda.

This study used the secondary data that are available from the Rwanda Demographic and Health Survey (2015) data. Through this survey, a total number of 13,497 females aged between 15 and 49 years and 6,217 males of 15 to 59 years age responded to the DHS questionnaire. A total number of 12,699 households were questioned countrywide within November 9, 2014, to April 8, 2015 at National level.

The RDHS 2015 gathered information about demographic and health status of families including mothers, fathers and children in questioned households. It provides information about the identification of the mothers and fathers, their level of education, area of residence and several other issues nationwide. Among other issues, household living condition and the infection of diarrhea for children born from a woman were also addressed.

As stated above, different files covered all the needed information for this survey (Rwcouple's file, Rw Household's file, RwChildren's file and RwIndividual's file). The children's file contains responses to questions related to the identification of the mother for every child, the antenatal care, the environmental and socioeconomic factors of his/her welfare (the roof, floor material of the house, the children and mothers' antenatal or postnatal care, age of the parents and children and the survival pattern over time of the children in last five years) among other issues. This file is created from the women's file based on their birth history. The Individual (Women's) file consists of the background of the mother, the reproduction status, contraceptive use, pregnancy and postnatal care, the child immunization and health, the child and mother's nutrition, the marriage and sexual activity, the fertility preference, the husband's background and woman's work, HIV/AIDS and other STDs, other Health and Welfare issues. Questions related to registered births in the last five years, in the last year and in the month of interview or related to the current pregnancy were asked to women. only the Children's file and the Individual's (Women) file provide all the necessary information about every individual mother and child of the sample. The merging of these two files can also allow selecting all explanatory variables for the under-five diarrhea in Rwanda since they combine both mothers' characteristics as well as their children. The study is a two step analysis. The first step involves the determination of risk factors associated with the episode of diarrhea 
whereas the second step involves the exploration of the effect of diarrhea on child mortality. Thus, for the first step the criteria will be: Inclusion criteria: children whose full records on diarrhea status variable, children aged below five years and children whose full records on diarrhea infection status variable. Exclusion criteria: children without records on diarrhea status variable, children out of the age of 59 months and children without records on diarrhea infection status variable. The criteria for the second step will be: Inclusion criteria: children whose full records on mortality status variable and children aged below five years. Exclusion criteria: children without records on mortality status variable and children out of the age of 59 months.

\section{Table 1: Measurement and recoding of independent variables to be used in the analysis}

In RDHS 2015, only $\mathbf{7 4 7 4}$ children meet the step 1 inclusion criteria and therefore they will be taken as the sample in the phase one analysis of the study. And 2957 meet the second step inclusion criteria and therefore they will be taken as the sample in the second step analysis of the study. The management of data will involve the measurement and the recoding of independent variables to be included in the analysis. The recording system intends to make variables operational along the analysis, the fact being that most of them are classified in more than 3 values. It presents variables that were judged to be relevant for the analysis, these variables being classified in indirect and direct factors. The direct factors involve the type of floor material, source of drinking water, type of cooking energy, type of toilet facility, Time to get to water source and Toilet facility shared with other households. The indirect factors include mother's level of education , mother's age, anemia level of the child, number of under five children, current age of the child, month of interview, type of place, sex of child, religion and wealth index.

The data management will be followed by analysis using statistical packages such as STATA13 and SPSS20. All research questions were answered with the help of the results of logistic regressions except question 1 that answered by using descriptive analysis results. The bivariate analysis allowed us to explain the relationship of each independent variable on the outcome variable. This relationship allowed a sound selection of variables having a significant association to childhood diarrhea in Rwanda. The multiple logistics regressions helped us to identify useful variables in making the prediction of the hypothesis. This means that, on the basis of a set of independent variables (e.g. the level of education of the mother, the place of delivery...) helped us to know the association between each independent variable while controlling for other variables in predicting the binary dependent variable (child had diarrhea or not) for a specific time period (two weeks).

Table 2: Analysis Plan, (2019) 


\section{Variables}

\section{Demographic variables}

Month of interview (V006) recoded into season

Respondent current age (V012) recorded into agecat

Births in last five years (V208)

Anemia level (hw57) recorded into anemia status

Mothers' education level(v106)

Sex of the child (b4) not recoded nor computed, taken directly from RDHS 2015

Current age of the child in months (hw1)

\section{Specification on value recoding}

1 through $2=1($ dry $)$, others $=2$ (rainy)

Lowest through $18=1,18$ through $34=2,35$ and highest $=3$

0 through $2=1$ (normal), $>=3=2$ (severe)

1 through $3=1$ (anemic), 4=2(not anemic)

$0=0$ (no education), $1=1$ (primary), 2 through

$3=2$ (secondary and higher)

$1=$ male and $2=$ female

0 through $5=0$ (Newborn), 6 through $11=1,12$ through $23=2,24$ through $35=3$ and 36 through $59=4$

\section{Socio-economic variables}

Type of place of residence (V025) ), not recoded nor computed, taken directly from RDHS 2015

Religion (V130)recorded into religiousness

Wealth index (V190) recorded into poverty

$1=$ urban, $2=$ Rural

1 through $5=1$ (religious $)$ and others $=($ Not religious)

1 through $2=1$ (poor), $3=3$ (middle) and 4 through $5=2$ (rich)

\section{Infrastructure and sanitation}

Time to get to water source(v115) recorded into time

Source of drinking water (v113) recorded into water

1 through $30=1$ (short), 31 through $240=2$ (long), 3 ( on premises)

11 through $13=1$ (piped water), Others $=2$ (open well water)

\section{Household living condition variables}

Type of toilet facility(v116) Recorded into Toilet

$11=1$ (flush toilet), 20 through $22=2$ (pit and traditional toilet), $30=3$ (no toilet facility

Main floor material (V127) recorded into Floor

30 through 34=2 (improved material=cement, ceramic tiles.. ), 0thers $=1$ (Rudimentary, earth..)

Toilet facility shared with other households (V160) ), not recoded nor computed, taken directly from

RDHS 2015

\section{Dependent variables}

Had diarrhea recently $(\mathrm{H} 11)$, not recoded nor computed, taken directly from RDHS 2015
$1=$ No and $2=$ yes last two weeks 
Child is alive(b5), not recoded nor computed, taken $\quad 1=$ No and $2=$ yes

directly from RDHS 2015

\section{Policy Contribution}

In 2015, global communities have been agreed on 17 SDGs to follow MDGs for which 3 of them concerned with health of children: SDG 3's (ensure healthy lives and promote well-being for all at all ages) second target (3.2) focused on child survival and eighth target (3.8) focused on access to essential medicines and vaccines for all. However, the higher prevalence of infectious diseases hinders the achievement of those targets. Thus, the findings of this study will be used to highlight predictors of diarrhea prevalence among under-five children in Rwanda and then controlled for better outcome (low prevalence of diarrhea) which will lead to the early achievement of the new SDG target on child health of reducing mortality to at least as low as 25 deaths per 1000 live births in children under the age of 5 years by 2030 .

\section{Results And Discussions}

\subsection{Descriptive results: Childhood diarrhea prevalence}

The figure 3 below indicates a two weeks prevalence among under-five children in Rwanda in 2015. Thus, the same as the findings of RDHS2015; the same figure indicates the prevalence were $12.1 \%$.

\section{Socio- economic and demographic Characteristics of sampled children}

The following table summarizes the children, households and environmental related information in favor of variables included in the analysis and their relationship with the childhood diarrhea prevalence and then demonstrates the plausibility of Genser B. et al theory.

Table 3: Frequency distribution of all Variables in the Analysis and their Relationship with childhood diarrhea status (Binary child had diarrhea or not)

The results of the table 4 above confirm the ones of the RDHS2015. For instance, the childhood diarrhea prevalence is highly concentrated in rural areas (16\%) against $10.3 \%$ (in urban areas); among household sharing the same toilet facilities (13.4\%) against $11.2 \%$ (not shared); among male children (12.6\%) against $11.6 \%$ (females); among anemic children (16.3\%) against $11.7 \%$ (not anemic); among children born with mother whose any formal education or primary education $(13.6 \%$, and $12.5 \%$ respectively) against $8.7 \%$ (those whose at least secondary education); particularly among children aged between [611 months (17.0\%) and between [12-23] months (24.2\%) this is due to the change in nutritional status because in the same age groups children begin to be weaned and consume foods other than breast milk. 


\begin{tabular}{|c|c|c|c|c|}
\hline Research questions & Dimensions & $\begin{array}{l}\text { Independent } \\
\text { variables }\end{array}$ & $\begin{array}{l}\text { Dependent } \\
\text { variable }\end{array}$ & $\begin{array}{l}\text { Analysis } \\
\text { method }\end{array}$ \\
\hline \multirow{15}{*}{$\begin{array}{l}\text { 1. What are the risk factors } \\
\text { associated with the under-five } \\
\text { diarrhea in Rwanda? }\end{array}$} & $\begin{array}{l}\text { demographic } \\
\text { factors }\end{array}$ & $\begin{array}{l}\text { Respondent } \\
\text { current age }\end{array}$ & \multirow{6}{*}{$\begin{array}{l}\text { Binary } \\
\text { child had } \\
\text { diarrhea or } \\
\text { not }\end{array}$} & \multirow{6}{*}{$\begin{array}{l}\text { Bivariate } \\
\text { and } \\
\text { multivariate } \\
\text { analysis }\end{array}$} \\
\hline & & $\begin{array}{l}\text { Mothers' } \\
\text { education } \\
\text { level }\end{array}$ & & \\
\hline & & $\begin{array}{l}\text { Births in last } \\
\text { five years }\end{array}$ & & \\
\hline & & $\begin{array}{l}\text { Month of } \\
\text { interview }\end{array}$ & & \\
\hline & & $\begin{array}{l}\text { Sex of the } \\
\text { child }\end{array}$ & & \\
\hline & & $\begin{array}{l}\text { Current age } \\
\text { of the child } \\
\text { in months }\end{array}$ & & \\
\hline & \multirow[t]{5}{*}{$\begin{array}{l}\text { environmental } \\
\text { factors }\end{array}$} & $\begin{array}{l}\text { Time to get } \\
\text { to water } \\
\text { source }\end{array}$ & \multirow[t]{5}{*}{$\begin{array}{l}\text { Binary } \\
\text { child had } \\
\text { diarrhea or } \\
\text { not }\end{array}$} & \multirow[t]{5}{*}{$\begin{array}{l}\text { Bivariate } \\
\text { and } \\
\text { multivariate } \\
\text { analysis }\end{array}$} \\
\hline & & $\begin{array}{l}\text { Source of } \\
\text { drinking } \\
\text { water }\end{array}$ & & \\
\hline & & $\begin{array}{l}\text { Type of toilet } \\
\text { facility }\end{array}$ & & \\
\hline & & $\begin{array}{l}\text { Main floor } \\
\text { material }\end{array}$ & & \\
\hline & & $\begin{array}{l}\text { Toilet facility } \\
\text { shared with } \\
\text { other } \\
\text { households }\end{array}$ & & \\
\hline & \multirow{4}{*}{$\begin{array}{l}\text { socio- } \\
\text { economic } \\
\text { factors }\end{array}$} & Religion & \multirow{4}{*}{$\begin{array}{l}\text { Binary } \\
\text { child had } \\
\text { diarrhea or } \\
\text { not }\end{array}$} & \multirow{4}{*}{$\begin{array}{l}\text { Bivariate } \\
\text { and } \\
\text { multivariate } \\
\text { analysis }\end{array}$} \\
\hline & & Wealth index & & \\
\hline & & $\begin{array}{l}\text { Type of } \\
\text { place of } \\
\text { residence }\end{array}$ & & \\
\hline & & $\begin{array}{l}\text { Anemia } \\
\text { level }\end{array}$ & & \\
\hline
\end{tabular}


1. What could be the effect of the episode of diarrhea in childhood on childhood mortality in Rwanda?
Demographic

factor
Binary child had diarrhea or not
Binary

child is

alive or

not
Bivariate analysis

Moreover, they correspond to the ages at which children begin to explore their environment, resulting in greater exposure to pathogens.

In addition, as argued by Genser B. and colleagues' theory, the economic status of household could make the affordability of hygienic practices difficult and then magnifies the risk of infection for children. Thus, the same table indicates that the higher prevalence of childhood diarrhea is noticeable among poor households (14.9\%) against 9.1\% (richer households). Moreover, the higher peak of prevalence were found among households that used more than 30 minutes to reach water source (12.5\%) against $7.1 \%$ ( those who had water in their houses); among households with no toilet facility(14.9\%); among households whose unimproved main floor (12.9\%) against 9\%(improved) and among households whose un improved water source (12.4) against 11.4\%(improved). Lastly, childhood diarrhea prevalence seems to bear some association with season because among households surveyed during rainy season showed a higher prevalence (12.5\%) against $11.6 \%$ (among those surveyed during dry season).

\subsection{Results of the Univariate Logistic Regression Analysis}

This section will allow us to explain the relationship existing between each independent variable and the outcome variable. This relationship will allow a sound selection of variables having a significant effect on childhood diarrhea in Rwanda. Both direct and indirect factors will be analyzed. 


\begin{tabular}{|c|c|c|c|c|}
\hline \multirow[t]{2}{*}{ Variables } & \multirow[t]{2}{*}{ Categories } & \multirow[t]{2}{*}{$\mathbf{N}$} & \multicolumn{2}{|c|}{ Had diarrhea recently } \\
\hline & & & No $F(\%)$ & $\begin{array}{l}\text { yes, last } \\
\text { two } \\
\text { weeks F } \\
(\%)\end{array}$ \\
\hline \multirow[t]{3}{*}{ Type of place of residence } & Urban & 1635 & $1467(89.7)$ & $168(10.3)$ \\
\hline & Rural & 5839 & $5102(87.4)$ & $737(12.6)$ \\
\hline & Total & 7474 & $6569(87.9)$ & $905(12.1)$ \\
\hline \multirow{5}{*}{$\begin{array}{l}\text { toilet facilities shared with } \\
\text { other households }\end{array}$} & No & 5527 & $4909(88.8)$ & $618(11.2)$ \\
\hline & Yes & 1600 & $1385(86.6)$ & $215(13.4)$ \\
\hline & not a de jure resident & 102 & $82(80.4)$ & $20(19.6)$ \\
\hline & Sub-total & 7229 & $6376(88.2)$ & $853(11.8)$ \\
\hline & Missing & 245 & & \\
\hline \multirow[t]{3}{*}{ sex of child } & male & 3766 & $3290(87.4)$ & $476(12.6)$ \\
\hline & female & 3708 & $3279(88.4)$ & $429(11.6)$ \\
\hline & Total & 7474 & $6569(87.9)$ & $905(12.1)$ \\
\hline \multirow[t]{3}{*}{ season } & Dry & 3177 & $2809(88.4)$ & $368(11.6)$ \\
\hline & Rainy & 4297 & $3760(87.5)$ & $537(12.5)$ \\
\hline & Total & 7474 & $6569(87.9)$ & $905(12.1)$ \\
\hline \multirow[t]{4}{*}{ respondent's current age } & [15-18] & 72 & 64(88.9) & $8(11.1)$ \\
\hline & {$[19-34]$} & 5211 & $4569(87.7)$ & $642(12.3)$ \\
\hline & [35-59] & 2263 & 1936(88.4) & $255(11.6)$ \\
\hline & Total & 7474 & $6569(87.9)$ & $905(12.1)$ \\
\hline \multirow[t]{4}{*}{ births in last five years } & {$[1-2]$} & & $6190(87.9)$ & $854(12.1)$ \\
\hline & & 7044 & & \\
\hline & [3-4] & 430 & $379(88.1)$ & $51(11.9)$ \\
\hline & Total & 7474 & $6569(87.9)$ & $905(12.1)$ \\
\hline \multirow[t]{3}{*}{ anemia status of a child } & Anemic & 1158 & $969(83.7)$ & 189(16.3) \\
\hline & Not Anemic & 2072 & $1829(88.3)$ & $243(11.7)$ \\
\hline & Sub-Total & 3230 & $2798(86.6)$ & $432(13.4)$ \\
\hline
\end{tabular}




\begin{tabular}{|c|c|c|c|c|}
\hline & & & & \\
\hline & Missing & 4244 & & \\
\hline \multirow[t]{4}{*}{ Mother's education level } & No education & 1067 & $922(86.4)$ & $145(13.6)$ \\
\hline & Primary & 5355 & $4686(87.5)$ & $669(12.5)$ \\
\hline & secondary or higher & 1052 & $961(91.3)$ & $91(8.7)$ \\
\hline & Total & 7474 & $6569(87.9)$ & $905(12.1)$ \\
\hline \multirow[t]{7}{*}{ age of the child in months } & {$[0-6]$} & 353 & $332(94.1)$ & $21(5.9)$ \\
\hline & {$[6-11]$} & 424 & $352(83.0)$ & 72(17.0) \\
\hline & [12-23] & 747 & $566(75.8)$ & $181(24.2)$ \\
\hline & [24-35] & 757 & $648(85.6)$ & $109(14.4)$ \\
\hline & {$[36-59]$} & 1334 & $1258(94.3)$ & $76(5.7)$ \\
\hline & Sub-Total & 3615 & $3156(87.3)$ & 459(12.7) \\
\hline & Missing & 3859 & & \\
\hline \multirow[t]{4}{*}{ Mother's religiousness } & Religious & 7428 & $6530(87.9)$ & $898(12.1)$ \\
\hline & Not religious & 39 & $32(82.1)$ & $7(17.9)$ \\
\hline & Sub-Total & 7467 & $6562(87.9)$ & $905(12.1)$ \\
\hline & Missing & 7 & & \\
\hline \multirow[t]{4}{*}{ Household poverty status } & Poor & 3345 & $2848(85.1)$ & 497(14.9) \\
\hline & Rich & 2708 & $2462(90.9)$ & $246(9.1)$ \\
\hline & Middle & 1421 & 1259(88.6) & $162(11.4)$ \\
\hline & Total & 7474 & $6569(87.9)$ & $905(12.1)$ \\
\hline \multirow{6}{*}{$\begin{array}{l}\text { Time used to get to water } \\
\text { source }\end{array}$} & $<30$ Min & 4289 & $3752(87.5)$ & $537(12.5)$ \\
\hline & >30Min & 2328 & 2033(87.3) & $295(12.7)$ \\
\hline & On premises & 751 & 698(92.9) & $53(7.1)$ \\
\hline & Not de jure resident & 102 & $82(80.4)$ & 20(19.6) \\
\hline & Sub-Total & 7470 & $6565(87.9)$ & $905(12.1)$ \\
\hline & Missing & 4 & & \\
\hline \multirow[t]{2}{*}{ Type of toilet facility } & Flush toilet & 92 & $89(96.7)$ & $3(3.3)$ \\
\hline & Pit and traditional toilet & 5009 & $4457(89.0)$ & $552(11.0)$ \\
\hline
\end{tabular}




\begin{tabular}{|c|c|c|c|c|}
\hline & No toilet & 2178 & $1854(85.1)$ & $324(14.9)$ \\
\hline & Not a de jure residence & 102 & $82(80.4)$ & $20(19.6)$ \\
\hline & Sub-Total & 7381 & 6482(87.8) & $899(12.2)$ \\
\hline & Missing & 93 & & \\
\hline \multirow[t]{5}{*}{ source of drinking water } & piped water & 2730 & $2420(88.6)$ & $310(11.4)$ \\
\hline & open well water & 4640 & 4065(87.6) & $575(12.4)$ \\
\hline & $\begin{array}{l}\text { Not de jure place of } \\
\text { residence }\end{array}$ & 102 & $82(80.4)$ & $20(19.6)$ \\
\hline & Sub-Total & 7472 & $6567(87.9)$ & $905(12.1)$ \\
\hline & Missing & 2 & & \\
\hline \multirow[t]{3}{*}{ Main floor materials } & Rudimentary, earth & 5653 & 4923(87.1) & $730(12.9)$ \\
\hline & $\begin{array}{l}\text { Improved material: cement, } \\
\text { ceramic tiles,... }\end{array}$ & 1709 & 1555(91.0) & 154(9.0) \\
\hline & Not a de jure residence & 102 & $82(80.4)$ & $20(19.6)$ \\
\hline Sub-Total & 7464 & $6560(87.9)$ & $904(12.1)$ & \\
\hline Missing & \multicolumn{3}{|l|}{10} & \\
\hline
\end{tabular}




\section{Demographic variables}

$\begin{array}{llllll}\text { Sex of the child (b4)/ Ref. Cat: } & \text { Female } & -0.101 & 0.156 & 0.904 & {[0.787,1.039}\end{array}$ Male

\begin{tabular}{|c|c|c|c|c|c|}
\hline Season/ Ref. Cat: Dry & Rainy & 0.086 & 0.231 & 1.090 & {$[0.946,1.256]$} \\
\hline \multirow[t]{2}{*}{ Agecat/ Ref. Cat: [15-18] } & [19-34] & 0.117 & 0.690 & 1.124 & {$[0.537,2.355]$} \\
\hline & [35-49] & 0.052 & 0.757 & 1.054 & {$[0.499,2.223]$} \\
\hline Births/Ref Cat: [1-2] & [3-4] & -0.025 & 0.871 & 0.975 & {$[0.722,1.318]$} \\
\hline Anemia status/Ref Cat: Anemic & Not Anemic & -0.384 & 0.000 & 0.681 & {$[0.555,0.837]$} \\
\hline \multirow{2}{*}{$\begin{array}{l}\text { Mother's education level/ Ref } \\
\text { Cat: no education }\end{array}$} & Primary & -0.097 & 0.326 & 0.908 & {$[0.749,1.101]$} \\
\hline & $\begin{array}{l}\text { Secondary or } \\
\text { higher }\end{array}$ & -0.507 & 0.000 & 0.602 & {$[0.456,0.794]$} \\
\hline \multirow{4}{*}{$\begin{array}{l}\text { Child's age/ Ref Cat: < } 6 \\
\text { months }\end{array}$} & [6-11] months & 1.174 & 0.000 & 3.234 & {$[1.944,5.378]$} \\
\hline & $\begin{array}{l}{[12-23]} \\
\text { Months }\end{array}$ & 1.621 & 0.000 & 5.056 & {$[3.154,8.103]$} \\
\hline & $\begin{array}{l}\text { [24-35] } \\
\text { Months }\end{array}$ & 0.978 & 0.000 & 2.659 & {$[1.637,4.321]$} \\
\hline & $\begin{array}{l}\text { [36- } \\
\text { 59]Months }\end{array}$ & -0.046 & 0.857 & 0.955 & {$[0.580,1.572]$} \\
\hline
\end{tabular}

\section{Socio-economic variables}

Type of place of residence (v025)/ Ref Cat: Urban

Religiousness/ Ref Cat:

Religious

Poverty/ Ref Cat: Poor
Rural

0.232

Not Religious $\quad 0.464$

Rich

Middle

Infrastructure and sanitation

Time to get water source/Ref Cat: [1-30] Min

Source of drinking water/ Ref

Cat: Piped water

\begin{tabular}{lcccc} 
[30-40]Min & 0.014 & 0.859 & 1.014 & {$[0.871,1.180]$} \\
\hline On premises & -0.634 & $\mathbf{0 . 0 0 0}$ & 0.531 & {$[0.396,0.712]$} \\
\hline $\begin{array}{l}\text { Not a de jure } \\
\text { residence }\end{array}$ & 0.533 & $\mathbf{0 . 0 3 6}$ & 1.704 & {$[1.037, .801]$} \\
$\begin{array}{l}\text { Open well } \\
\text { water }\end{array}$ & 0.099 & 0.186 & 1.104 & {$[0.953,1.279]$} \\
\hline Not a de jure & 0.644 & $\mathbf{0 . 0 1 2}$ & 1.904 & {$[1.152,3.148]$}
\end{tabular}


residence

\section{Household living condition variables}

\begin{tabular}{|c|c|c|c|c|c|}
\hline \multirow[t]{3}{*}{$\begin{array}{l}\text { Type of toilet facility/ Flush } \\
\text { toilet }\end{array}$} & $\begin{array}{l}\text { Pit and } \\
\text { traditional } \\
\text { toilet }\end{array}$ & 1.301 & 0.027 & 3.674 & {$[1.159,11.649]$} \\
\hline & No toilet & 1.646 & 0.005 & 5.184 & $\begin{array}{l}{[1.631} \\
16.481]\end{array}$ \\
\hline & $\begin{array}{l}\text { Not a de jure } \\
\text { residence }\end{array}$ & 1.979 & 0.002 & 7.236 & $\begin{array}{l}{[2.073} \\
25.256]\end{array}$ \\
\hline \multirow{2}{*}{$\begin{array}{l}\text { Main floor material/ Ref Cat: } \\
\text { Un improved }\end{array}$} & Improved & -0.404 & 0.000 & 0.668 & {$[0.556,0.802]$} \\
\hline & $\begin{array}{l}\text { Not a de jure } \\
\text { residence }\end{array}$ & 0.498 & 0.049 & 1.645 & {$[1.003,2.698]$} \\
\hline $\begin{array}{l}\text { Toilet facilities shared with } \\
\text { other households (v160). Ref } \\
\text { Cat: No }\end{array}$ & Yes & 0.109 & 0.001 & 1.115 & {$[1.045,1.190]$} \\
\hline
\end{tabular}

Table 4: Summary of bivariate Analysis, (2019)

The above summary of univariate analysis revealed that among demographic variables included in the study, only being aged below three years old: infant (OR: 3.234, p: 0.000, C.I: [1.944, 5.378]), under 2 years (OR: 5.056, p: 0.000, C.I: [3.154, 8.103]) and under 3 years (OR:2.659, P: 0.000, C.I: [1.637, 4.321]) increases the chances of being infected by diarrhea whereas being anemia free ( OR: 0.681, P: 0.000, C.I: $[0.555,0.837])$ and having a mother whose at least secondary education (OR: 0.602, P: 0.000, C.I: [0.456, $0.794])$ reduces the chances of being infected by diarrhea.

The same table indicates that among the socio-economic variables included in the analysis, only being living in rural areas (OR: 1.261, P: 0.010, C.I: $[1.056,1.056])$ increases the likelihood of being infected by diarrhea whereas being living in a middle or rich family (OR: 0.737, P: 0.002, C.I:[0.610, 0.891); OR: 0.573, P: 0.000, C.l: $[0.487,0.673]$ respectively)reduces the likelihood of being infected by diarrhea.

As far as environmental factors is considered, all household living condition, infrastructure and sanitation related variables included in the study showed a significant effect on the childhood diarrhea. For instance having water on premise (OR: V, P: 0.000, C.I: [0.396, 0.712]), having improved Main floor in a household (OR: $0.668, \mathrm{P}: 0.000, \mathrm{C} . \mathrm{I}:[0.556,0.802])$ reduces also the likelihood of being infected by diarrhea for underfive children whereas being sharing toilet facilities with other households (OR:1.115, P: 0.001, C.I:[1.045, 1.190] ), having no toilet or pit and traditional toilet in a household (OR: 5.184, P: 0.005, C.I: [1.631, 16.481]; OR: 3.674, P: 0.027, C.I: $[1.159,11.649])$ increases the chances of being infected by diarrhea for an under-five child. Note that also de facto residence increases the likelihood of being infected by diarrhea.

\subsection{Results of the multivariate logistic regression analysis}


The variables found to be significantly associated with childhood diarrhea in the univariate analysis were maintained in the forward conditional logistic regression to account for the change in effect when all predictors are present as seen in table 6 below:

\begin{tabular}{|c|c|c|c|c|c|}
\hline Iterations & Variables & B & $\mathbf{P}$ & OR & 95\% C.I. \\
\hline \multirow[t]{5}{*}{ Step $1^{\mathrm{a}}$} & Child's age/ [6-11] months & & 0.000 & & \\
\hline & [12-23] Months & 0.467 & 0.004 & 1.595 & {$[1.158,2.198]$} \\
\hline & [24-35]Months & -0.130 & 0.454 & 0.878 & {$[0.625,1.234]$} \\
\hline & [3-39]Months & -1.215 & 0.000 & 0.297 & {$[0.206,0.427]$} \\
\hline & Constant & -1.644 & 0.000 & 0.193 & \\
\hline \multirow[t]{8}{*}{ Step $2^{b}$} & Poverty/ Poor & & 0.000 & & \\
\hline & Rich & -0.473 & 0.000 & 0.623 & {$[0.487,0.797]$} \\
\hline & Middle & -0.352 & 0.020 & 0.703 & {$[0.522,0.946]$} \\
\hline & Child's age/ [6-11] months & & 0.000 & & \\
\hline & [12-23] Months & 0.465 & 0.005 & 1.592 & {$[1.154,2.197]$} \\
\hline & [24-35]Months & -0.144 & 0.409 & 0.866 & {$[0.615,1.219]$} \\
\hline & [3-39]Months & -1.224 & 0.000 & 0.294 & {$[0.204,0.424]$} \\
\hline & Constant & -1.417 & 0.000 & 0.243 & \\
\hline \multirow[t]{12}{*}{ Step $3^{c}$} & Type of toilet facility/ Flush toilet & & 0.019 & & \\
\hline & Pit and traditional toilet & 0.749 & 0.470 & 2.115 & {$[0.277,16.148]$} \\
\hline & No toilet & 1.115 & 0.285 & 3.050 & {$[0.396,23.522]$} \\
\hline & Not a de jure residence & 1.141 & 0.324 & 3.131 & {$[0.325,30.185]$} \\
\hline & Poverty & & 0.013 & & \\
\hline & Rich & -0.351 & 0.008 & 0.704 & {$[0.544,0.911]$} \\
\hline & Middle & -0.312 & 0.041 & 0.732 & {$[0.543,0.987]$} \\
\hline & Child's age/ [6-11] months & & 0.000 & & \\
\hline & [12-23] Months & 0.462 & 0.005 & 1.587 & {$[1.150,2.191]$} \\
\hline & [24-35]Months & -0.134 & 0.445 & 0.875 & {$[0.621,1.232]$} \\
\hline & [3-39]Months & -1.223 & 0.000 & 0.294 & {$[0.204,0.424]$} \\
\hline & Constant & -2.328 & 0.026 & 0.097 & \\
\hline
\end{tabular}


The above table presents outputs of a forward conditional logistic multivariate analysis for all independent variables that proved to be significant with the dependent variable in the univariate analysis where only one variable among demographic, socio-economic and environmental variables is retained in the results. The odds of 1.587 indicates that a child aged between [12-23] months is about 1.6 times less likely to be infected by diarrhea compared to the one aged between [6-11] months (P: 0.005, C.I: [1.150, 2.191])other regressors held constant. It further indicates that there is no significant difference in probabilities when the age group of [24-35] months is considered. Moreover, the odds of 0.294 indicates that by holding other regressors at constant value, a child aged between [3-39] months is about 3.4 times less likely to be infected by diarrhea compared to the infant (p: 0.000, C.I: [0.204, 0.424]).

The other included variable is the household poverty status. Thus, in the same table the odds of 0.704 indicates that by holding other regressors at constant value, a child living in a richer family is about 1.4 less likely to be infected by diarrhea compared to the one who is living in a poorer family (p: 0.008, C.I: $[0.544,0.911])$. In addition, the odds of 0.732 indicates that a child living in a family whose middle income is about 1.35 times less likely to be infected by diarrhea compared to the one living in a poorer family (p: 0.041, C.I: [0.522, 0.946]). Other variables held constant.

As far as type of toilet facility is considered the p_value of 0.019 indicates that childhood diarrhea is associated with type of toilet facility in favor of absence or un improved toilet as sen in the univariate analysis.

\subsection{Discussion of the Results}

Rwanda as many other developing countries (especially sub-Saharan Africa) has a higher childhood diarrhea prevalence which leads to child's mortality. The main linked causes outlined by the univariate and multivariate are direct (Sharing toilet facilities with other household members, Type of toilet facilities, time to get water source, source of drinking water andHouse floor material) and indirect (Mother's level of education, type of place of residence of the mother, anemia level of the child, age of the child and family poverty status). These ten causes inter-linkedly have an effect on each other to reach the high rate of childhood diarrhea infection as well under-five mortality. One can observe that type of toilet facility, sharing toilet facility with other household, main floor material and time to get water source could be associated with the level of education and the family's poverty status. This goes in line with what Genser B. and colleagues said through their following statement: "Poor socioeconomic status (SES) increases diarrhoea risk, mostlymediated by lack of sanitation, poor infrastructure and living conditions (Genser B. et al, 2008, pp.1). As expected, there is a higher prevalence of childhood diarrhea in Rwanda $(12.11 \%$ against $11 \%$ ). Moreover, demographic, socio-economic and environmental factors determine the overall prevalence level of childhood diarrhea in Rwanda as confirmed by the logistic analysis. On the other hand this study failed to confirm the plausibility of (Bethesda J. $O$ et al. 2017) and (Ayuk B. et al. 2015) related 
to the influence of mother ageand number of under-five siblingsin a household respectively on the childhood diarrhea status.

Apparently, poverty was a major determinant of diarrhea (attributablerisk: $24 \%$ ). Most of the effect of socio-economic status was closely related to other more proximate diarrhea determinants such as lack of sanitation, inadequateenvironmental infrastructure and poor living conditions. However, further research is needed to assess the extent of influence of income level on childhood diarrhea infection in Rwanda.

In conclusion, our study shows that sanitation affordabilityespecially in rural areas can have a substantial impact on the epidemiology of child diarrhea. Improving sanitation decreases the attributablerisk of diarrhea determinants directly by reducing exposure to these factors, or indirectly by changing the strength of associations with them

\section{Conclusions \& Policy Recommendations}

\subsection{Conclusions}

The overall aim was to sort out the risk factors of childhood diarrhea in Rwanda. On the basis of outputs, $12.1 \%$ of the selected sample (7474) of children aged below five years during the time of interview reported to have diarrhea in the preceding two weeks. The univariate and multivariate (reduced model) analysis further traces a demarcation between the observed under five diarrhea picture and its main determinants. The univariatedepicted fiveindependent direct determinant variables ( Sharing toilet facilities with other household members, Type of toilet facilities, time to get water source, source of drinking water and House floor material) and five indirect variables (Mother's level of education, type of place of residence of the mother, anemia level of the child, age of the child and family poverty status) that influence significantly the overall picture of childhood diarrhea in Rwanda. The multivariate attempting to check the overall effect of each significant selected variable when controlling for other variables in the reduced model found out that childhood diarrhea is mainly determined by the age of the child (below 35 months), by the household poverty and by the presence or absence of pit and traditional toilet.

\subsection{Research and Policy recommendations}

There is an interaction of different factors leading to higher childhood diarrhea in Rwanda especially below the age of three years. Poverty was found to be the main determinants that influence the sanitation practices as well as infrastructure and household living condition. Thus:

a)The government of Rwanda should expand the existing child health programs and put more emphasis on environmental sanitation components targeting mothers and child caregivers on better ways of handling children between the age of 29-36 months who were established to be at a higher risk than older and younger children probably due to exposure to environmental contamination. b) The government in collaboration with WASAC should make water available and accessible to all Rwandans especially those 
living in rural areas at every time. c) The government should elaborate a framework of mobilization to the general public about the hygienic practices in a regular form.

\section{Conflict of interest.}

There is no conflict of interest for both authors or institutions to publish this study at the international journals.

\section{References}

Africa Health Observatory, \& WHO. (2016). RWANDA Factsheets of Health Statistic.

Centers for Disease Control and Prevention. (2014). Diarrhea: Common Illness, Global Killer. U.S. Department of Health and Human Services. Retrieved from https://www.cdc.gov/healthywater/pdf/global/programs/globaldiarrhea508c.pdf

Danquah, L., Mensah, C. M., Agyemang, S., \& Awuah, E. (2015). Risk Factors Associated with Diarrhea Morbidity Among Children Younger than Five Years in the Atwima Nwabiagya District, Ghana: A CrossSectional Study. Science Journal of Public Health. https://doi.org/10.11648/j.sjph.20150303.17

Ganguly, E., Sharma, P. K., \& Bunker, C. H. (2015). Prevalence and risk factors of diarrhea morbidity among under-five children in India: A systematic review and meta-analysis.

Genser, B., Strina, A., Prado, Barreto, \& Cairncross. (2008). Impact of a city-wide sanitation intervention in a large urban centre on social, environmental and behavioural determinants of childhood diarrhoea: analysis of two cohort studies.

KIMANI, H. M. (2013). Assessement Of Diarrhoeal Disease Attributable To Water, Sanitation And Hygiene Among Under Five In Kasarani, Nairobi County. Kenyatta University.

MOH. (2014). Rwanda Annual Health Statistics Booklet.

MOH. (2015). Monitoring \& Evaluation Plan for the Health Sector Strategic Plan (Hssp lii): 2014-2018. Retrieved from http://www.moh.gov.rw/fileadmin/templates/MOH-

Reports/Final_M_E_plan_for_HSSP_III_A..pdf

Mohammed, A., \& Zungu, L. (2016). Environmental health factors associated with diarrhoeal diseases among under-five children in the Sebeta town of Ethiopia. Southern African Journal of Infectious Diseases. https://doi.org/10.1080/23120053.2016.1156876

Mosley, W., \& Chen, L. (1984). An Analytical Framework for the Study of Child Survival in Developing Countries. 
Nasser, S. (2014). Socio-demographic, socio-economic and household environmental characteristics associated with diarrheal disease among children under five years of age in Ethiopia. Stockholm University.

Ngabo, F., Mvundura, M., Gazley, Gatera, Rugambwa, \& Kayonga. (2016). The Economic Burden Attributable to a Child's Inpatient Admission for Diarrheal Disease in Rwanda.

NISR, MINECOFINE, MOH, ICF International, \& USA. (2016). Rwanda Demographic and Health Survey 2014-15 Final Report.

O Connell, B. J., Quinn, M. A., \& Scheuerman, P. (2017). Risk factors of diarrheal disease among children in the East African countries of Burundi, Rwanda and Tanzania, 6.

RBC. (2013). Maternal, Neonatal And Child Health National Strategy (pp. 2-3). Ministry of Health.

RBC. (2015). Community Assessment On Water, Hygiene And Sanitation In Response To Cholera Outbreak In Rusizi And Nyamasheke Districts. Retrieved from http://www.rbc.gov.rw/fileadmin/user_upload/community_assessment_cholera_executive_summary2.pdf

Simms, C., Milimo, \& Bloom. (1993). The Reasons For The Rise In Childhood Mortality During the 1980s in Zambia. Retrieved from https://www.ids.ac.uk/files/Wp76.pdf

Sinharoy, S. S., Schmidt, Cox, Clemence, Mfura, Wendt, ... Gr_epin. (2016). Child diarrhoea and nutritional status in rural Rwanda: a cross-sectional study to explore contributing environmental and demographic factors, 21.

UN. (2013). Study by the World Health Organization on mortality among children under five years of age as a human rights concern.

UNICEF. (2015). Diarrhoea remains a leading killer of young children, despite the availability of a simple treatment solution.

Unicef, The World Bank Group, Who, \& Un. (2015). Levels \& Trends in Child Mortality (p. 4). new york.

Uwizeye, D., okoni, C. H., \& Kabiru, C. W. (2014). Prevalence and correlates for diarrhoea in the mountainous informal settlements of Huye town, Rwanda. Springer Plus. https://doi.org/10.1186/21931801-3-745

WHO. (2015). Global Health Observatory (GHO) data [global database]. Retrieved from http://www.who.int/gho/child_health/mortality/causes/en/

WHO. (2017a). Diarrhoeal disease. Retrieved from http://www.who.int/mediacentre/factsheets/fs330/en/ 
WHO. (2017b). Diarrhoeal disease [Media Center]. Retrieved from

http://www.who.int/mediacentre/factsheets/fs330/en/

Genser B. et al (2008). Impact of a city-wide sanitation intervention in a large urban centre on social, environmental and behavioural determinants of childhood diarrhoea: analysis of two cohort studies. International Journal of Epidemiology, 3.

Lancet. (2017). Estimates of global, regional, and national morbidity, mortality, and aetiologies of diarrhoeal diseases: a systematic analysis for the Global Burden of Disease Study. Lancet Infectious Disease.

\section{Figures}

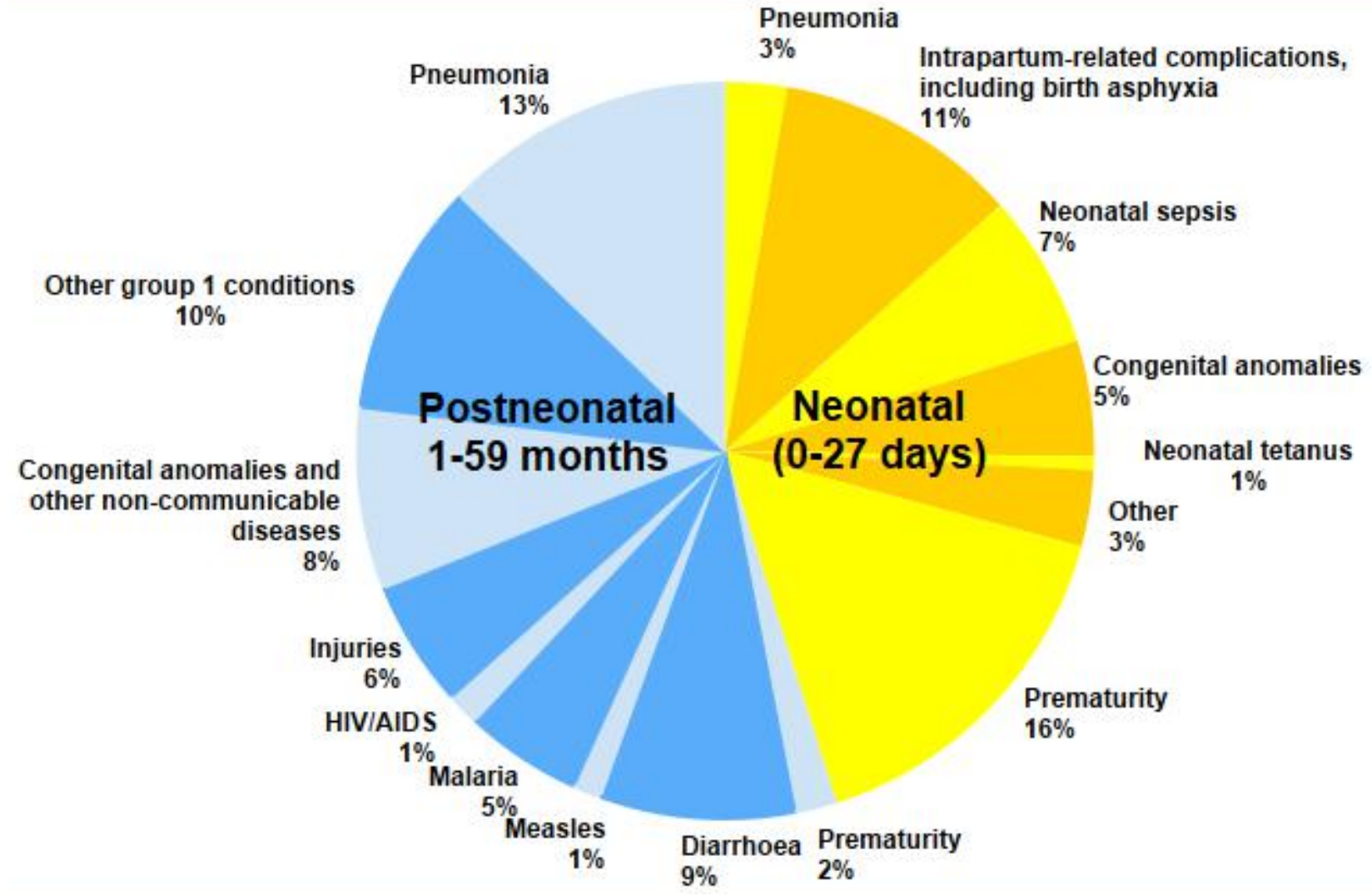

\section{Figure 1}

Causes of under five deaths world wide 


\begin{tabular}{|c|c|c|c|c|c|c|c|c|c|}
\hline \multirow[b]{2}{*}{ Region } & \multicolumn{6}{|c|}{ Under-five deaths (thousands) } & \multirow{2}{*}{$\begin{array}{c}\text { Decline } \\
\text { (percent) } \\
\text { 1990-2015 }\end{array}$} & \multicolumn{2}{|c|}{$\begin{array}{l}\text { Share of global under- } \\
\text { five deaths (percent) }\end{array}$} \\
\hline & 1990 & 1995 & 2000 & 2005 & 2010 & 2015 & & 1990 & 2015 \\
\hline Developed regions & 223 & 154 & 129 & 111 & 96 & 80 & 64 & 1.7 & 1.3 \\
\hline Developing regions & 12,526 & 10,840 & 9,654 & 8,189 & 6,917 & 5,865 & 53 & 98.3 & 98.7 \\
\hline Northern Africa & 280 & 194 & 142 & 121 & 111 & 114 & 59 & 2.2 & 1.9 \\
\hline Sub-Saharan Africa & 3,871 & 4,079 & 4,114 & 3,748 & 3,292 & 2,947 & 24 & 30.4 & 49.6 \\
\hline Latin America and the Caribbean & 632 & 494 & 378 & 280 & 258 & 196 & 69 & 5.0 & 3.3 \\
\hline Caucasus and Central Asia & 145 & 120 & 88 & 72 & 68 & 62 & 58 & 1.1 & 1.0 \\
\hline Eastern Asia & 1,662 & 851 & 615 & 424 & 266 & 194 & 88 & 13.0 & 3.3 \\
\hline Eastern Asia excluding China & 28 & 42 & 30 & 18 & 15 & 12 & 55 & 0.2 & 0.2 \\
\hline Southern Asia & 4,796 & 4,154 & 3,566 & 2,916 & 2,398 & 1,891 & 61 & 37.6 & 31.8 \\
\hline Southern Asia excluding India & 1,439 & 1,215 & 1,053 & 872 & 803 & 690 & 52 & 11.3 & 11.6 \\
\hline South-eastern Asia & 856 & 702 & 542 & 457 & 371 & 331 & 61 & 6.7 & 5.6 \\
\hline Western Asia & 270 & 231 & 192 & 156 & 136 & 117 & 57 & 2.1 & 2.0 \\
\hline Oceania & 14 & 15 & 16 & 16 & 15 & 13 & 6 & 0.1 & 0.2 \\
\hline World & 12,749 & 10,994 & 9,783 & 8,299 & 7,013 & 5,945 & 53 & 100.0 & 100.0 \\
\hline
\end{tabular}

\section{Figure 2}

Levels and trends in the number of deaths of children under age five, by Millennium Development Goal region

\begin{tabular}{|l|r|l|}
\hline Diseases groups & Number of cases & $\%$ \\
\hline Malaria & 192,132 & $37 \%$ \\
\hline Pneumonia & 118,068 & $23 \%$ \\
\hline Diarrhea & 103,044 & $20 \%$ \\
\hline Febrile disease & 33,650 & $7 \%$ \\
\hline Skin Infection & 15,913 & $3 \%$ \\
\hline Ear infection & 14,744 & $3 \%$ \\
\hline Bacterial infection & 7,360 & $1 \%$ \\
\hline Diarrhea with dehydration & 7,276 & $1 \%$ \\
\hline Conjunctivitis purulent of newborn, IMCI & 6,488 & $1 \%$ \\
\hline Urinary tract infections, IMCI & 6,307 & $1 \%$ \\
\hline Other & 11,480 & $2 \%$ \\
\hline & 516,462 & \\
\hline
\end{tabular}

\section{Figure 3}

Top ten causes of morbidity and mortality in $\mathrm{IMCl}$ in health centers 


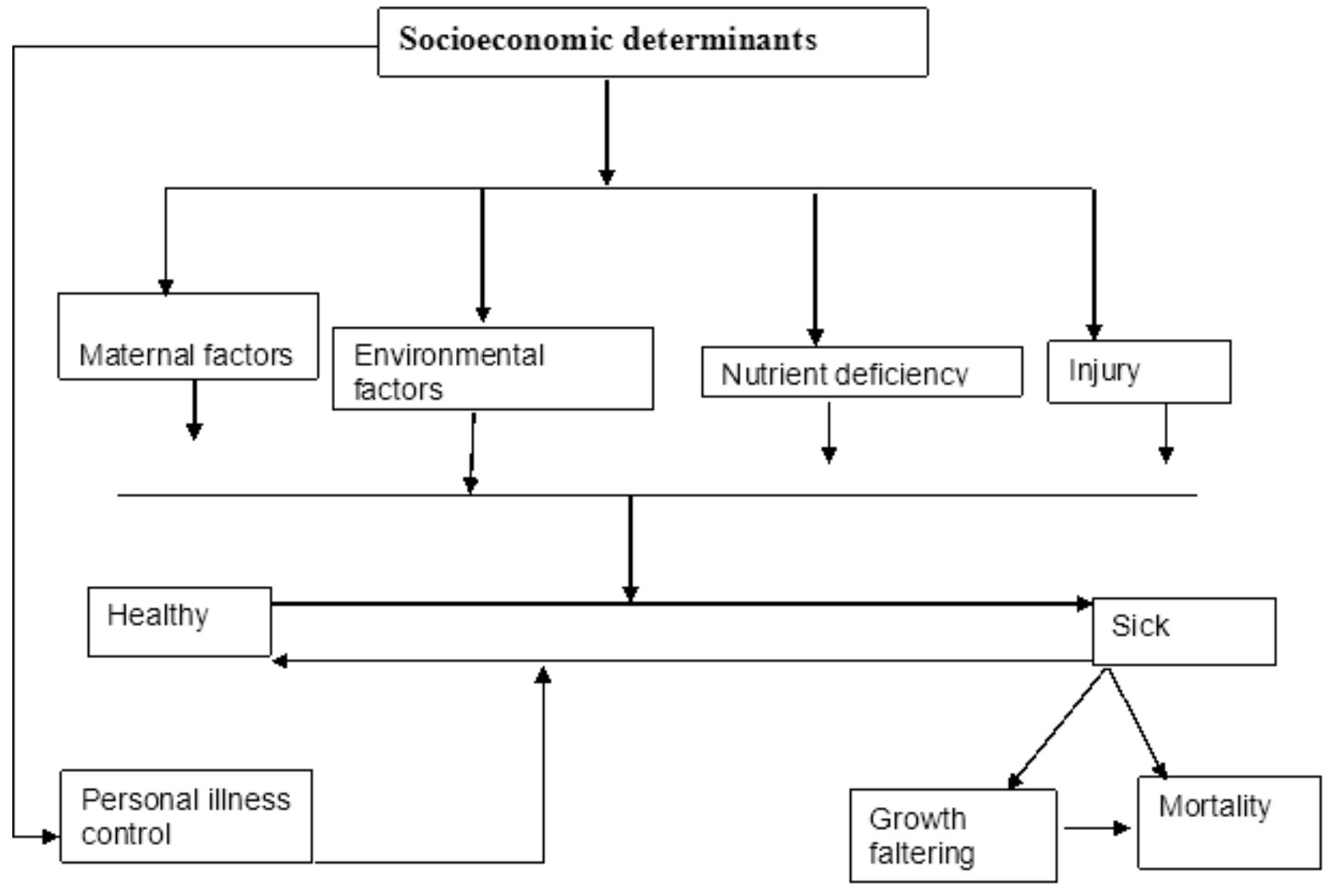

Figure 4

Mosley and Chen's model of under-five mortality determinants

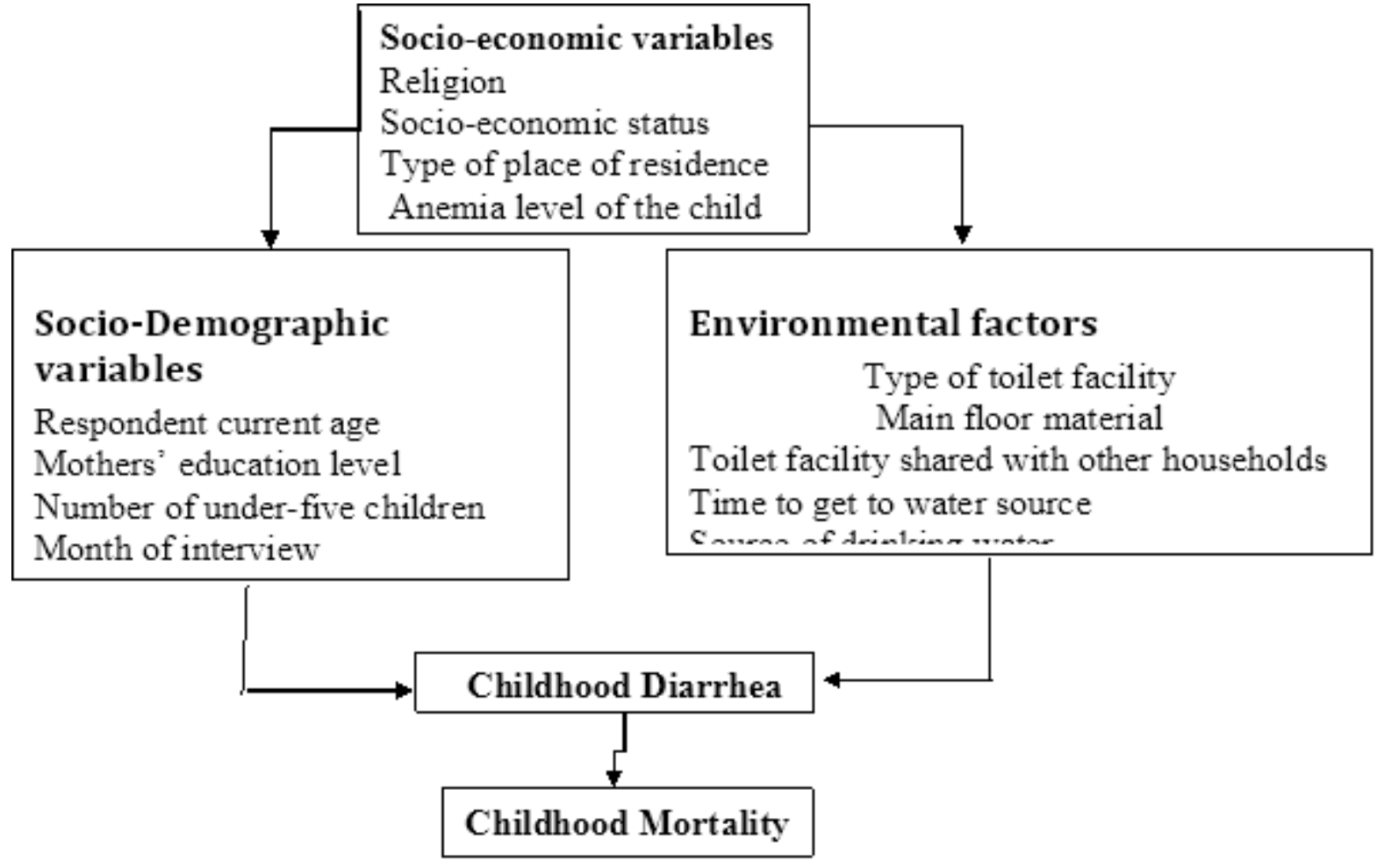

Figure 5 
Conceptual framework of the study

Page 28/28 